\title{
Photoperiod influenced the growth and antioxidative responses of Chlorella vulgaris, Isochrysis galbana, and Tetraselmis chuii
}

\author{
Nurul Shafiqa Yusof ${ }^{1}$, Yik Sung Yeong ${ }^{1,2}$, Hazlina Ahamad Zakeri ${ }^{3,4}$, Mohd Effendy Abdul Wahid ${ }^{1,2}$, Sarah Nabila Ab \\ Ghafar $^{3}$, Norhayati Yusuf ${ }^{3,4 *}$ \\ ${ }^{1}$ Institute of Marine Biotechnology, Universiti Malaysia Terengganu, Kuala Nerus, Malaysia. \\ ${ }^{2}$ Faculty of Fisheries and Food Sciences, Universiti Malaysia Terengganu, Kuala Nerus, Malaysia. \\ ${ }^{3}$ Faculty of Science and Marine Environment, Universiti Malaysia Terengganu, Kuala Nerus, Malaysia. \\ ${ }^{4}$ Biological Security and Sustainability Research Interest Group BIOSES, Universiti Malaysia Terengganu, Kuala Nerus, Malaysia.
}

\begin{tabular}{|c|c|}
\hline ARTICLE INFO & ABSTRACT \\
\hline $\begin{array}{l}\text { Received on: } 29 / 11 / 2020 \\
\text { Accepted on: } 21 / 02 / 2021 \\
\text { Available online: } 05 / 04 / 2021\end{array}$ & $\begin{array}{l}\text { Microalgae are rich in natural antioxidants, with occurrence and quality depending primarily on the species of } \\
\text { microalgae and the conditions of cultivation. Light and photoperiod affect microalgae accumulation of antioxidants. } \\
\text { This study examined the growth, biomass, and antioxidant responses of microalgae Chlorella vulgaris (UMT-M1), } \\
\text { Isochrysis galbana (CB), and Tetraselmis chuii (CT) grown in } 30 \mathrm{ppt} \mathrm{F/2-enriched} \mathrm{seawater} \mathrm{and} \mathrm{exposed} \mathrm{to} \mathrm{12:12}\end{array}$ \\
\hline $\begin{array}{l}\text { Key words: } \\
\text { Growth, biomass, } \\
\text { antioxidants, photoperiod, } \\
\text { microalgae. }\end{array}$ & $\begin{array}{l}\text { and } 24: 0 \text { hours light/dark cycles at } 24^{\circ} \mathrm{C} \pm 2^{\circ} \mathrm{C} \text {. Overall cell density, wet biomass, chlorophyll a, chlorophyll b, } \\
\text { carotenoids, and ascorbic acid content of UMT-M1, CB, and CT increased upon continuous light exposure for } 8 \text { days } \\
(p<0.05) \text {. Constant light exposure induced } \alpha \text {-tocopherol accumulation in UMT-M1 and CT microalgae but not CB. } \\
\text { Results indicated that as a response to continuous light treatment, UMT-M1, CB, and CT may exert natural antioxidant } \\
\text { protection mechanism. }\end{array}$ \\
\hline
\end{tabular}

\section{INTRODUCTION}

Microalgae contain lipids, carbohydrates, proteins, pigments, essential fatty acids, antioxidants, and vitamins (Mobin et al., 2019; Nethravathy et al., 2019; Safafar et al., 2015), where all bioactive compounds are potentially useful in pharmaceutical and nutraceutical applications (Mobin et al., 2019). In particular, antioxidant compounds have been exploited for use in human healthcare and therapeutic product formulation, and in this sense, natural microalgae antioxidants are considered a valuable resource compared to synthetic antioxidants obtained from chemical processes (Safafar et al., 2015; Smerilli et al., 2019; Tan et al., 2020). The synthetic antioxidants have raised many human health concerns and controversies; for instance, they trigger liver

\section{${ }^{*}$ Corresponding Author}

Norhayati Yusuf, Faculty of Science and Marine Environment, Universiti Malaysia Terengganu, Kuala Nerus, Malaysia; Biological Security and Sustainability Research Interest Group (BIOSES), Universiti Malaysia Terengganu, Kuala Nerus, Malaysia.E-mail: yatiyusuf@umt.edu.my damage and carcinogenesis (Hamidi et al., 2020). Contrary to artificial antioxidants, microalgae are the ultimate choice to meet the incremental demands in the perspective of human population growth as they are fast growing with high biomass, aimed at complementing the antioxidant production from traditional plants (Barkia et al., 2019; Sansone and Brunet, 2019).

Microalgae are photosynthetic organisms that use light, carbon dioxide, and water to produce food in the form of biological macromolecules like proteins, lipids, and carbohydrates (Morales et al., 2019). Light and photoperiod affect the growth and yield of microalgae during cultivation (Ahmad et al., 2020; Zhang et al., 2019). In addition, the period of light and dark exposure until the saturation point at which the maximal photosynthetic rate is reached may control cellular contents (Darvehei et al., 2018; Sirisuk et al., 2018), including chlorophyll and antioxidants (Maroneze et al., 2016). Light promotes the synthesis of various bioactive compounds (Chandra et al., 2016; Mobin et al., 2019; Ye et al., 2017) in which they play a pivotal role in suppressing the development of reactive oxygen species (ROS) from molecular oxygen $\left(\mathrm{O}_{2}\right)$ in chloroplasts, as well as mitochondria, apoplasts, 
and peroxisomes (Noshi et al., 2016), with superoxide anion radical $\left(\mathrm{O}_{2}{ }^{--}\right)$, singlet oxygen $\left({ }^{1} \mathrm{O}_{2}\right)$, hydroxyl radical $(\bullet \mathrm{OH})$, and hydrogen peroxide $\left(\mathrm{H}_{2} \mathrm{O}_{2}\right)$ (Assunção et al., 2017; Khorobrykh et al., 2020). Constant illumination may cause an imbalance between ROS output and its scavengers (Khorobrykh et al., 2020). Excessive ROS development promotes oxidative damage to lipids and other molecules in cytosols or within chloroplasts, and in this regard, microalgae provide a wide array of antioxidants to combat oxidative stress (Mobin et al., 2019; Szymańska et al., 2017). Antioxidants consist of enzymatic (superoxide dismutase, peroxidase, and catalase) and nonenzymatic groups (watersoluble vitamin $\mathrm{C}$, lipid-soluble vitamin $\mathrm{E}$, and quenchers such as $\beta$-carotene) (Assunção et al., 2017; Yu et al., 2017). Antioxidant production generally depends on the form and period of stress as well as the species of microalgae (Szymańska et al., 2017; Yu et al., 2017).

Up until now, most of the research conducted with microalgae focused on biomass production (Che et al., 2019; Kato et al., 2019; Ren et al., 2020; Vendruscolo et al., 2019; Zhang et al., 2019) and determination of the cellular contents such as lipid (Che et al., 2019; Kato et al., 2019; Medved et al., 2020; Ren et al., 2020; Vendruscolo et al., 2019; Zhang et al., 2019), fatty-acid (Che et al., 2019; Kato et al., 2019; Vendruscolo et al., 2019), chlorophyll (Gonzalez-Camejo et al., 2019; Patel et al., 2019; Vendruscolo et al., 2019), protein (Medved et al., 2020; Vendruscolo et al., 2019; Zhang et al., 2019), and carbohydrate content (Chong et al., 2019; Kato et al., 2019; Medved et al., 2020) upon the variations in the light and dark exposure. The role of photoperiods in the development of antioxidants and their responses to microalgae, however, is poorly understood. The goal of this study was to determine the effect of the photoperiod on growth and antioxidant responses of three species of marine microalgae, Chlorella vulgaris, Isochrysis galbana (CB), and Tetraselmis chuii (CT), commonly found in tropical brackish and marine environments. This evaluation is important to extend the knowledge of optimizing the culture conditions of microalgae with high antioxidants producing capacity.

\section{MATERIALS AND METHODS}

\section{Microalgae stock and inoculum culture}

Chlorella vulgaris (UMT-M1), CB, and CT obtained from Institute of Marine Biotechnology, Universiti Malaysia Terengganu, Terengganu, Malaysia, were grown with F/2 medium containing $\mathrm{NaNO}_{3}(0.88 \mathrm{mM}), \mathrm{NaH}_{2} \mathrm{PO}_{4}(0.036 \mathrm{mM}), \mathrm{Na}_{2}$ EDTA. $\mathrm{H}_{2} \mathrm{O}(0.012 \mathrm{mM}), \mathrm{FeCl}_{3} .6 \mathrm{H}_{2} \mathrm{O}(0.012 \mathrm{mM}), \mathrm{MnCl}_{2} .4 \mathrm{H}_{2} \mathrm{O}(0.91$ $\mu \mathrm{M}), \quad \mathrm{ZnSO}_{4} .7 \mathrm{H}_{2} \mathrm{O}(0.077 \mu \mathrm{M}), \mathrm{CoCl}_{2} .6 \mathrm{H}_{2} \mathrm{O}(0.042 \mu \mathrm{M})$, $\mathrm{Na}_{2} \mathrm{MoO}_{4} .2 \mathrm{H}_{2} \mathrm{O}(0.026 \mu \mathrm{M}), \mathrm{CuSO}_{4} .5 \mathrm{H}_{2} \mathrm{O}(0.039 \mu \mathrm{M})$, thiamine$\mathrm{HCl}(0.30 \mu \mathrm{M})$, biotin $(8.84 \mathrm{nM})$, and cyanocobalamin $(0.37 \mathrm{nM})$ (Guillard, 1975; Guillard and Ryther, 1962) at 30 ppt salinity and $\mathrm{pH} 8.0 \pm 0.2$. The cultures were incubated at $24^{\circ} \mathrm{C} \pm 2{ }^{\circ} \mathrm{C}$ under constant illumination (2,000 lux) using $6,500 \mathrm{~K}$ daylight white light emitting diode lamp. The aeration Hailea HAP-120 pump (Hailea Group Co., China) was supplied with an airflow rate of around $120 \mathrm{l} /$ minutes of air under the pressure of $0.018 \mathrm{MPa}$, filtered through a $0.22 \mu \mathrm{m}$ Minisart ${ }^{\circledR}$ Sartorius syringe filter to avoid contamination. The cultivation of stock culture was first introduced in $100 \mathrm{ml}$ of the liquid medium in a $250 \mathrm{ml}$ flask before upscaling to $500 \mathrm{ml}$ took place. The inoculum cultures were upscaled to $450 \mathrm{ml}$ of the liquid medium in $500 \mathrm{ml}$ conical flasks and harvested at $1 \times 10^{6}$ cells $/ \mathrm{ml}$ prior to use in experiments. Microalgae were tested for purity and density and subsequently inoculated into separate flasks for use in photoperiod experiments.

\section{Photoperiod treatment}

Microalgae inoculated from the stock cultures were grown under two photoperiod conditions; one was given continuous illumination (24:0 hours light/dark cycles) and the other 12 hours light (12:12 hours light/dark cycles), respectively. The scaled-up inoculum was culture and treated accordingly until the end of the exponential phase ( 8 days). The 12 hours light (12:12 hours light/dark cycles) was controlled with a 24-hour programmed electrical timer (MS1144, Eurosafe, Malaysia). Experiments were conducted in three batches of cultivation with three biological replications for each batch, followed by three technical replicates in individual biological replicate. The detailed experimental setup of continuous and 12 hours light was shown in Figure 1.

\section{Determination of microalgae growth and biomass}

\section{Cell density}

Cell density was estimated regularly for 13 days. Approximately $200 \mu \mathrm{l}$ of the cultures was diluted with $800 \mu \mathrm{l}$ of Lugol solution (White et al., 2014). $10 \mu \mathrm{l}$ of the diluted solution was transferred to the Neubauer hemocytometer and the cells were counted using a compound microscope (Leica CME, Leica Microsystems GmbH, Germany) (Sahastrabuddhe, 2016). Cell densities were determined using the following formula:

$$
\text { Cell density }(\text { cells } / \mathrm{ml})=\frac{\begin{array}{c}
\text { Total number of cells } \times \text { dilution } \\
\text { factor }
\end{array}}{\begin{array}{c}
\text { Total number of squares } \times \text { Volume of } \\
\text { the square at } 0.01 \mathrm{~mm} \text { depth }
\end{array}}
$$

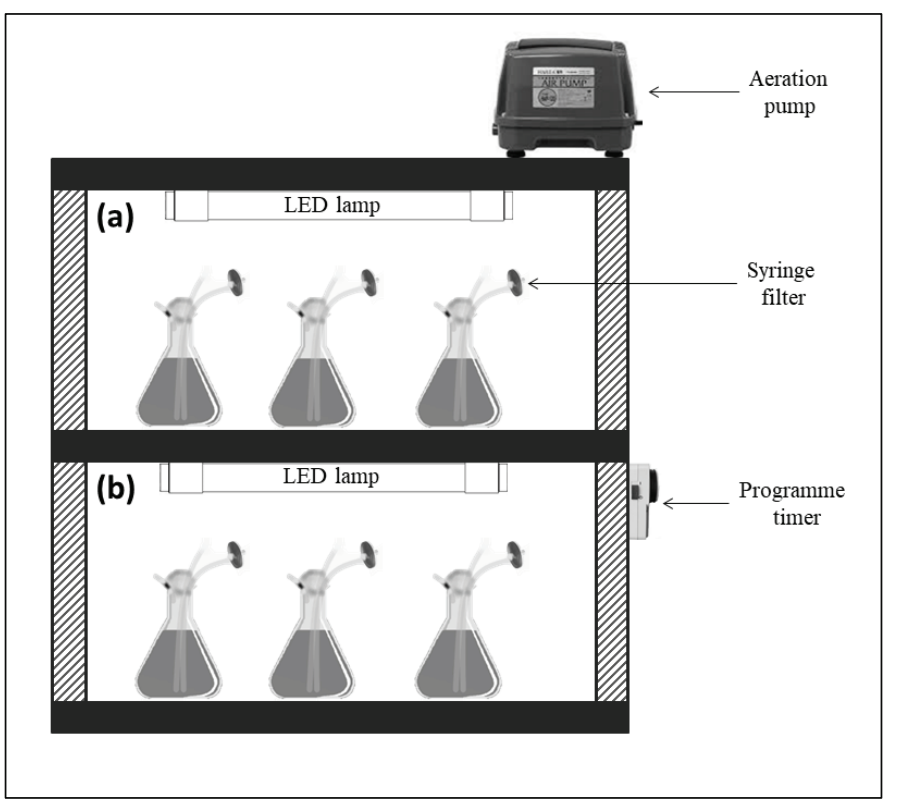

Figure 1. Experimental setup of (a) 24:0 hours L/D and (b) 12:12 hours L/D treatments. 


\section{Wet and dry biomass determination}

The wet and dry biomass of microalgae were determined on day 8 (at the end of the exponential and early stationary phase). $50 \mathrm{ml}$ culture was centrifuged 10 minutes with an Allegra X-30R Centrifuge, Beckman Coulter, Inc., Krefeld, Germany at $1,000 \times \mathrm{g}$. The supernatant was discarded and wet microalgae paste was washed twice with the same amount of distilled water. Microalgae paste was weighed with a balance (ME204, Mettler Toledo, Switzerland) and the wet biomass was recorded in $\mathrm{g} / \mathrm{l}$. The wet paste was dried in the oven at $70^{\circ} \mathrm{C} \pm 2^{\circ} \mathrm{C}$ for 24 hours until a constant weight was obtained, with the latter reported as dry biomass (g/l) (Kong et al., 2011). The remaining microalgae culture was centrifuged at $1,000 \times \mathrm{g}$ for 10 minutes and microalgae cells were harvested for antioxidant assays.

\section{Determination of antioxidative assays}

Chlorophylls and carotenoids contents determination

The content of chlorophylls and carotenoids was determined as essentially defined by Torres et al. (2014). Approximately $0.05 \mathrm{~g}$ of fresh microalgae cells was homogenized for 10 minutes with $1.5 \mathrm{ml}$ of absolute methanol using an ultrasonic bath (Fisherbrand ${ }^{\mathrm{TM}}$ Elmasonic S $60 \mathrm{H}$, Fisher Scientific, Schwerte, Germany) at $0^{\circ} \mathrm{C}-4^{\circ} \mathrm{C}$. The homogenate was centrifuged (Microfuge 20R Centrifuge, Beckman Coulter, Inc., Krefeld, Germany) at $9,168 \times \mathrm{g}$ for 10 minutes at $4^{\circ} \mathrm{C} .200 \mu \mathrm{l}$ of supernatant was transferred to a 96 -well plate, with $200 \mu \mathrm{l}$ of absolute methanol used as control. The plate was shaken in a microplate reader for 10 seconds (Varioskan ${ }^{\mathrm{TM}}$ LUX, Thermo Fisher Scientific, Vantaa, Finland). The chlorophylls and carotenoids absorbance were measured at 470, 653, and $666 \mathrm{~nm}$ (Lichtenthaler and Wellburn, 1983). The chlorophylls and carotenoids contents were calculated using the following formula:

Chlorophyll a, Chl a (mg/g FW)

$$
=15.65\left(A_{666}\right)-7.34\left(A_{653}\right) \times \frac{V}{1,000 \times \mathrm{FW} \times d}
$$

Chlorophyll b, Chl b (mg/g FW)

$$
=27.05\left(A_{653}\right)-11.21\left(A_{666}\right) \times \frac{V}{1,000 \times \mathrm{FW} \times d}
$$

Carotenoids (mg/g FW)

$=\frac{1,000\left(A_{470}\right)-2.86(\mathrm{Chl} \mathrm{a})-129.2(\mathrm{Chl} \mathrm{b})}{245} \times \frac{V}{1,000 \times \mathrm{FW} \times d}$

where $A$ is the absorbance value; $V$ is the total extract volume; FW is the microalgal fresh weight; and $d$ is the light path length.

\section{Ascorbic acid content determination}

Ascorbic acid content was determined following the procedures by Norhayati et al. (2016) with minor modifications. $1 \mathrm{ml}$ of $10 \%$ trichloroacetic acid was applied to $0.05 \mathrm{~g}$ fresh microalgae cells and then homogenized for 10 minutes using an ultrasonic bath (Fisherbrand ${ }^{\mathrm{TM}}$ Elmasonic S 60H, Fisher Scientific, Germany) at $0^{\circ} \mathrm{C}-4^{\circ} \mathrm{C}$. The homogenates were centrifuged (Microfuge 20R Centrifuge, Beckman Coulter, Inc., Krefeld, Germany) at 9,168 for 10 minutes $\times \mathrm{g}$ in cold condition $\left(4^{\circ} \mathrm{C}\right) .30 \mu \mathrm{l}$ of the supernatant was then diluted to a total volume of $200 \mu$ with distilled water and subsequently transferred to a flat bottom 96well plate with $200 \mu \mathrm{l}$ of distilled water used as a control (blank). $20 \mu \mathrm{l}$ of $10 \%$ of the Folin-Ciocalteu reagent was applied. The plate was incubated in a microplate reader (Varioskan ${ }^{\mathrm{TM}} \mathrm{LUX}$, Thermo Fisher Scientific, Vantaa, Finland) at $25^{\circ} \mathrm{C}$ for 10 minutes, where a blue color would be formed. The absorbance was measured at $760 \mathrm{~nm}\left(A_{760}\right)$ and the ascorbic acid value was calculated on a standard ascorbic acid curve $(y=0.022 \times-0.0015)$ constructed at a concentration of $0-5 \mu \mathrm{g} / \mathrm{ml}$. The content of ascorbic acid was calculated using the following formula:

Ascorbic acid (mg / g FW) $=\left(\frac{A+0.0015}{0.022}\right)\left(\frac{V r m \times V e b}{d \times V e \times \mathrm{FW}}\right)\left(\frac{\mathrm{df}}{1,000}\right)$

where $A$ is the absorbance value; $V \mathrm{rm}$ is the total reaction mixture volume in well; $V$ eb is the total extraction buffer volume; $d$ is the light path length; $V$ e is the total extract volume in well; FW is the microalgal fresh weight; and df is the dilution factor.

\section{$\alpha$-Tocopherol content determination}

$\alpha$-Tocopherol content was determined using methods adapted by Norhayati et al. (2016) with minor modifications. Approximately $0.05 \mathrm{~g}$ of fresh microalgae cells was homogenized with $1.5 \mathrm{ml}$ of absolute acetone in cold $\left(0^{\circ} \mathrm{C}-4^{\circ} \mathrm{C}\right)$ for 10 minutes. The mixture was extracted with $0.5 \mathrm{ml}$ hexane and then homogenized with an ultrasonic bath (Fisherbrand ${ }^{\mathrm{TM}}$ Elmasonic S $60 \mathrm{H}$, Fisher Scientific, Germany) for 10 minutes at $0^{\circ} \mathrm{C}-4^{\circ} \mathrm{C}$. Homogenates were then centrifuged (Microfuge 20R Centrifuge, Beckman Coulter, Inc., Germany) for 10 minutes at 9,168 $\times \mathrm{g}$ in cold condition $\left(4^{\circ} \mathrm{C}\right)$. After centrifugation, the upper layer of the supernatant was removed and the hexane extraction was repeated twice. $25 \mu \mathrm{l}$ of hexane extract was transferred to the flat bottom of the 96-well plate, with $25 \mu \mathrm{l}$ of absolute ethanol used as control. Then $20 \mu \mathrm{l}$ of $0.1 \%$ 3-(2-pyridyl)-5,6-diphenyl-1,2,4 triazine and $20 \mu \mathrm{l}$ of $0.1 \%$ ferric chloride were added to the layer. $85 \mu \mathrm{l}$ of absolute ethanol was applied to the microplate reader (Varioskan ${ }^{\mathrm{TM}}$, Thermo Fisher Scientific, Finland) for color production before the plate incubation at $25^{\circ} \mathrm{C}$ for 4 minutes. $10 \mu \mathrm{l}$ of $0.2 \mathrm{M}$ orthophosphoric acid was added to the mixture. The microplate was incubated at $25^{\circ} \mathrm{C}$ for another 10 minutes in the microplate reader prior to the $554 \mathrm{~nm}\left(A_{554}\right)$ absorbance measurement. The $\alpha$-tocopherol value was calculated based on the standard curve $(y$ $=0.0045 \times+0.0046)$ constructed at a concentration of $0-5 \mu \mathrm{g} / \mathrm{ml}$. The content of $\alpha$-tocopherol was measured using the following formula:

$$
\alpha \text { - Tocopherol (mg / g FW) }=\left(\frac{A-0.0046}{0.0045}\right)\left(\frac{V r m \times V e b}{d \times V e \times \mathrm{FW}}\right)\left(\frac{1}{1,000}\right)
$$

where $A$ is the absorbance value; $V \mathrm{rm}$ is the total reaction mixture volume in well; $V$ eb is the total extraction buffer volume; $d$ is the light path length; $V \mathrm{e}$ is the total hexane extract volume in well; $\mathrm{FW}$ is the microalgal fresh weight; and df is the dilution factor.

\section{Statistical analysis}

Statistical analysis was performed using Statistical Package for Social Science software version 20. The mean comparisons were evaluated using a one-way analysis of variance 
analysis. Multiple mean comparisons were determined by the Tukey test, while a comparison between 12:12 and 24:0 hours L/D cycles in each species was analyzed using a paired $t$-test sample. The differences were considered to be significant at $p<0.05$. Bivariate (Pearson) correlations were conducted to evaluate the hypotheses of association between cell density, biomass (wet and dry), and antioxidative responses like chlorophyll a, chlorophyll b, carotenoids, ascorbic acid, and $\alpha$-tocopherol.

\section{RESULTS AND DISCUSSION}

\section{Effect of photoperiod on microalgae growth and biomass}

Photoperiod affected the cell density and biomass of C. vulgaris (UMT-M1), CB, and CT during culture. The cell densities of UMT-M1, CB, and CT were higher in 24:0 hours L/D cycle than in 12:12 hours L/D cycle (Fig. 2), but only
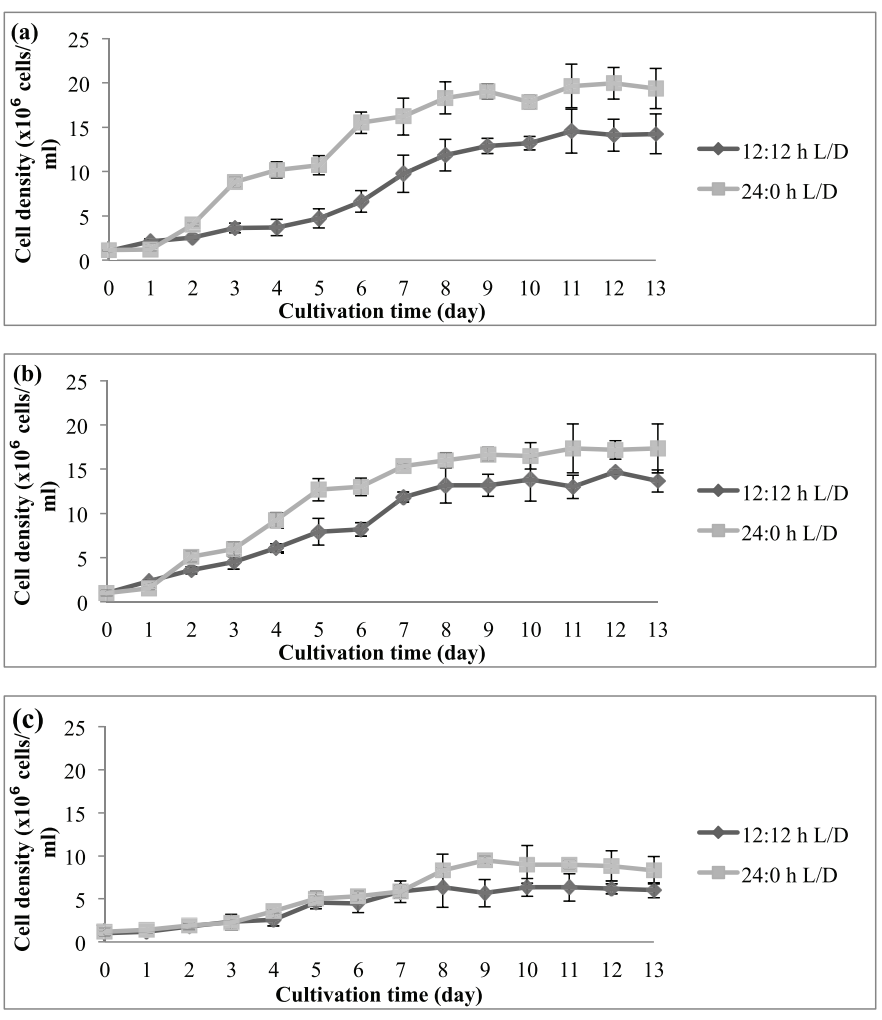

Figure 2. Cell density of (a) UMT-M1, (b) CB, and (c) CT cultivated under 12:12 and 24:0 hours L/D cycles. Data were reported as mean \pm standard deviation $(n=3)$.
UMT-M1 and CT were significantly higher $(p<0.05)$ in 8 days of continuous light exposure (Table 1). The wet biomass obtained for UMT-M1, CB, and CT samples grown under constant light was higher $(p<0.05)$ compared to $12: 12$ hours $\mathrm{L} / \mathrm{D}$, observations consistent with Maroneze et al. (2016) analysis. It was discovered that, with constant illumination, Scenedesmus obliquus, a green microalga, achieved maximum cell density and biomass. Similar findings have been obtained with Nannochloropsis sp. when constant light was provided at 50 and $100 \mu \mathrm{mol} \mathrm{m} \mathrm{m}^{-2} \mathrm{~s}^{-1}$ (Wahidin et al., 2013) as well as $N$. salina and Phaeodactylum tricornutum at $250 \mu \mathrm{mol} \mathrm{m} \mathrm{m}^{-2} \mathrm{~s}^{-1}$ (Sirisuk et al., 2018). On the contrary, I. galbana reached optimum density when the culture was carried out with a $12: 12$ hours L/D cycle at $400 \mu \mathrm{mol} \mathrm{m} \mathrm{m}^{-2}$ $\mathrm{s}^{-1}$ (Che et al., 2019), suggesting that certain microalgae species do not need constant light to achieve maximum growth, as in the case of Neochloris conjuncta, $N$. terrestris, and $N$. texensis reported by Krzemińska et al. (2014). Interestingly, this study showed that the dry biomass of UMT-M1 grown with these two photoperiod cycles was significantly different, but this condition was not observed in $\mathrm{CB}$ and $\mathrm{CT}$, which showed that dry biomass is associated with cellular water content, which is dependent on microalgae organisms, cell size, and length of light exposure (Chioccioli et al., 2014; Khoeyi et al., 2012).

Under the light regime, the cellular water content can be affected by the size of cellular components such as nucleus, cytoskeleton, chloroplasts, and mitochondria (Aratboni et al., 2019; Chioccioli et al., 2014), as well as by the accumulation of photosynthetic-related biomass compounds such as starch, glycerol, and protein (Khan et al., 2018; Xu et al., 2016). The period of light exposure influences the growth and biomass of microalgae as they are parallel to the rate of photosynthesis and the metabolism of microalgae (Matos et al., 2017). Increasing the exposure to light may lead to an increase in the reproduction rate before the intensity of the saturation point is reached. Individual organisms vary in terms of light requirements, life cycles, and reproduction patterns. The culture conditions, therefore, have a major impact on the growth and biomass of microalgae (Krzemińska et al., 2014).

\section{Effect of photoperiod on antioxidative responses}

Chlorophylls, carotenoids, ascorbic acid, and tocopherol are major antioxidative response compounds. All these components effectively detoxify excessive ROS production (Papalia et al., 2019). Light absorption by photosynthetic microalgae occurs in chlorophyll a as well as accessory chlorophyll b and carotenoids

Table 1. Effect of photoperiod cycle on the wet and dry biomass of UMT-M1, CB, and CT.

\begin{tabular}{ccccc}
\hline Species & Photoperiod (L/D hour) & Cell density (cells/ml) & Wet biomass (g/l) & Dry biomass (g/l) \\
\hline UMT-M1 & $12: 12$ & $1.20 \times 10^{7} \pm 1.80 \times 10^{6} \mathrm{a}, \mathrm{b}^{*}$ & $2.735 \pm 0.184 \mathrm{a}^{*}$ & $0.268 \pm 0.023 \mathrm{a}, \mathrm{b}^{*}$ \\
& $24: 0$ & $1.87 \times 10^{7} \pm 1.15 \times 10^{6} \mathrm{c}$ & $4.536 \pm 0.044 \mathrm{~b}$ & $0.460 \pm 0.033 \mathrm{c}$ \\
CB & $12: 12$ & $1.32 \times 10^{7} \pm 2.02 \times 10^{6} \mathrm{a}$ & $2.618 \pm 0.049 \mathrm{a}^{*}$ & $0.251 \pm 0.010 \mathrm{a}$ \\
& $24: 0$ & $1.60 \times 10^{7} \pm 8.66 \times 10^{5} \mathrm{a}, \mathrm{c}$ & $4.417 \pm 0.124 \mathrm{~b}$ & $0.395 \pm 0.065 \mathrm{~b}, \mathrm{c}$ \\
CT & $12: 12$ & $6.33 \times 10^{6} \pm 2.31 \times 10^{6} \mathrm{~d}^{*}$ & $2.505 \pm 0.131 \mathrm{a}^{*}$ & $0.248 \pm 0.020 \mathrm{a}$ \\
& $24: 0$ & $8.33 \times 10^{6} \pm 1.89 \times 10^{6} \mathrm{~b}, \mathrm{~d}$ & $4.292 \pm 0.278 \mathrm{~b}$ & $0.432 \pm 0.100 \mathrm{c}$ \\
\hline
\end{tabular}

Data were reported as mean \pm standard deviation $(n=3)$. Values with different superscript letters in a column represent significantly different at $p<0.05$. The asterisk symbol (*) in a column represents a statistically significant difference between 12:12 and 24:0 hours L/D cycles between individual species. 

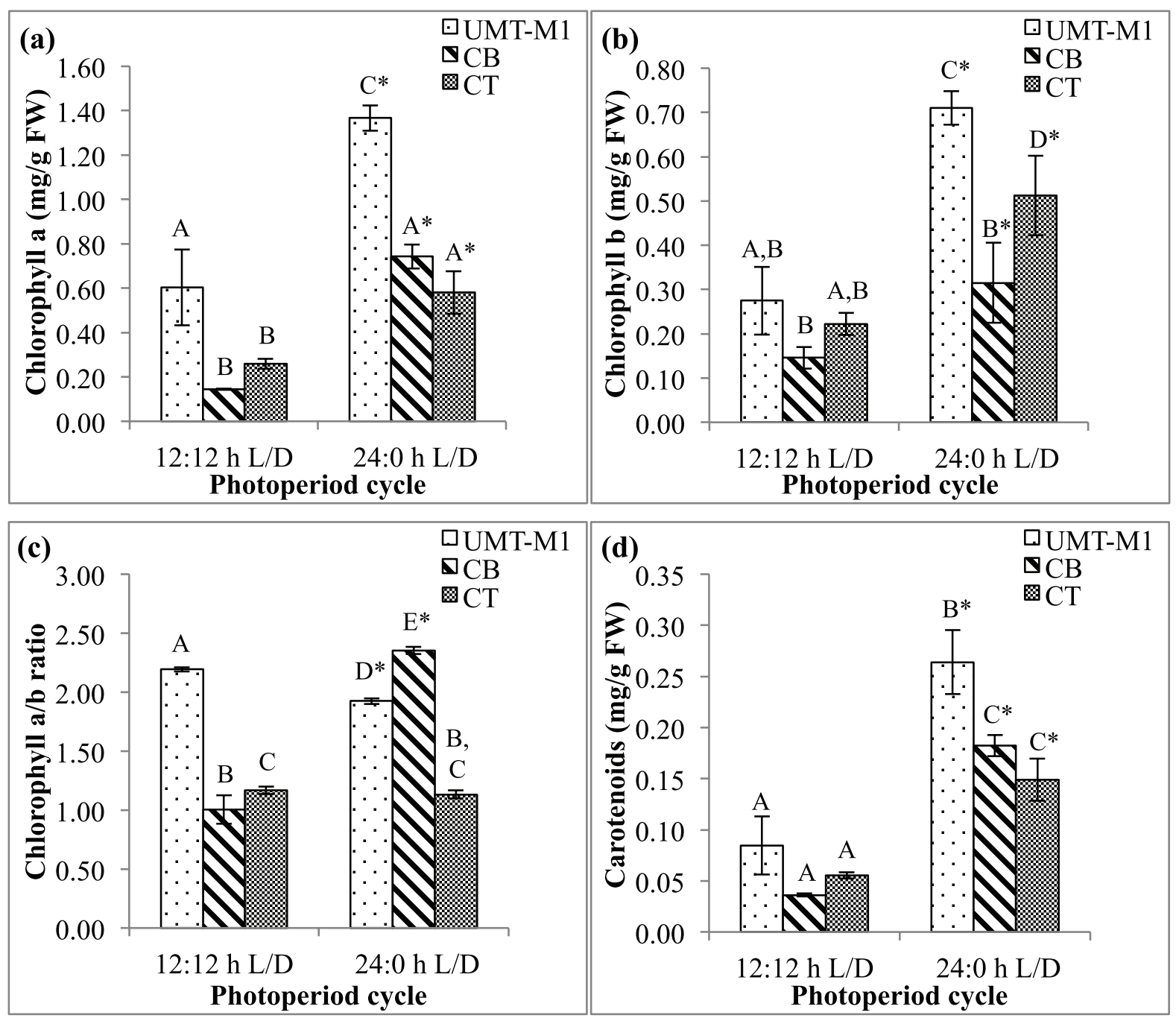

Figure 3. Chlorophyll a (a), chlorophyll b (b), chlorophyll a/b ratio (c) and carotenoids (d) contents of UMT-M1, CB, and CT cultivated under 12:12 and 24:0 hours $\mathrm{L} / \mathrm{D}$ cycles. Data were reported as mean of repetitions \pm standard deviation $(n=3)$. Values with different capital letters $(\mathrm{A}, \mathrm{B}, \mathrm{C}$, and $\mathrm{D})$ were statistically significantly different at $p<0.05$. The asterisk symbol $\left(^{*}\right)$ indicates that there was a significant difference between 12:12 and 24:0 hours L/D cycles between individual species.

(Sirisuk et al., 2018). Figure 3 shows the content of chlorophyll a, chlorophyll b, chlorophyll a/b ratio, and carotenoids in UMT-M1, $\mathrm{CB}$, and CT grown under different photoperiods. UMT-M1 contained the highest chlorophyll a $(1.366 \pm 0.057 \mathrm{mg} / \mathrm{g} \mathrm{FW})$, chlorophyll b $(0.711 \pm 0.038 \mathrm{mg} / \mathrm{g} \mathrm{FW})$, and carotenoids $(0.264$ $\pm 0.031 \mathrm{mg} / \mathrm{g} \mathrm{FW})$ but $\mathrm{CB}$ has the highest chlorophyll a/b ratio of three species. Interestingly, UMT-M1, CB, and CT chlorophyll $\mathrm{a}$, chlorophyll $\mathrm{b}$, and carotenoids were significantly induced $(p<$ $0.05)$ in 24:0 L/D compared to 12:12 hours L/D cycle. Compared to other microalgae species such as Ankistrodesmus falcatus, chlorophyll a and carotenoids were higher in cultivation with 12:12 hours L:/D cycle, whereas chlorophyll b remains higher in culture with constant light (George et al., 2014). In another study, the chlorophyll a of $S$. obliquus grown with $12: 12$ hours L/D cycle was higher than 24:0 L/D cycle but chlorophyll b content remained constant in both photoperiod conditions (Vendruscolo et al., 2019). In addition, chlorophyll $\mathrm{a} / \mathrm{b}$ ratio decreased in UMT-M1 but increased in CB while CT remained constant when continuous light was provided. These findings suggested that continuous illumination promotes chlorophyll $\mathrm{a}$ and $\mathrm{b}$ synthesis as well as carotenoid content in UMT-M1, CB, and CT, but the chlorophyll a/b ratio varies in these species.

On an applied note, the efficacy of microalgal chlorophyll a to capture light photons varies by pigment arrangement, cell structure, and chloroplast composition (Sirisuk et al., 2018). The elevation of chlorophyll a content as observed in this current study may be due to the increasing number of photosynthetic units during light harvesting, whereas the rise in chlorophyll b content may have been linked to the increment of photoprotection pigment during light exposure (Levasseur et al., 2018). The increase in the chlorophyll $\mathrm{a} / \mathrm{b}$ ratio indicates a relatively significant role for chlorophyll a in photosynthesis, whereas the decrease in the chlorophyll $\mathrm{a} / \mathrm{b}$ ratio suggests that chlorophyll $\mathrm{b}$ appears to be highly functional in photosynthesis, which is closely related to the shift in chlorophyll composition in the light-harvesting complex of thylakoid membranes in the reaction center of a photosystem (Beneragama and Goto, 2010; Negi et al., 2016; Perrine et al., 2012; Ramaraj et al, 2013). 
Carotenoids exist in chloroplast membranes and play a crucial role in light harvesting as well as in photo protecting photosynthetic systems against the illumination tension (Ma et al., 2018; Smerilli et al., 2019). Increasing carotenoids in UMT-M1, $\mathrm{CB}$, and $\mathrm{CT}$ under continuous light are therefore parallel to their involvement in alleviating and assisting the photosynthetic pigment-protein complex (Sirisuk et al., 2018). Carotenoids can quench peroxides and singlet oxygen thus inhibits the ROS formation (Smerilli et al., 2019). A balance between light energy harvesting in chloroplast and energy use during carbon fixation is needed to adapt light strain (Levasseur et al., 2018).

Besides chlorophyll and carotenoids, photoperiod also affects microalgae ascorbic acid accumulation. The ascorbic acid content of UMT-M1, CB, and CT vary considerably with exposure to the photoperiod conditions tested in this study $(p<$ 0.05 ) as portrayed in Figure 4. Notably, the ascorbic acid content of UMT-M1, CB, and CT was higher in continuous light culture with an accumulation of $1.460 \pm 0.167,0.924 \pm 0.044$, and 1.264 $\pm 0.086 \mathrm{mg} / \mathrm{g} F W$, respectively. Our findings showed that ascorbic acid production was enhanced under continuous illumination, with similar results in Desmonostoc salinum and S. quadricauda (De Alvarenga et al., 2020; Zahra et al., 2017). However, some microalgae species like Skeletonema marinoi do not show a shift in ascorbic acid content on crops with different light period (Smerilli et al., 2019).

Ascorbic acid (vitamin C), a water-soluble vitamin with antioxidant properties, can be used to scavenge ROS development under light stress (Galasso et al., 2019). De Alvarenga et al. (2020) stated that microalgae can produce 4-9 times ascorbic acid under continuous light. Ascorbic acid elevation in this study is possibly correlated with the ${ }^{1} \mathrm{O}_{2}$ scavenging role as the photosynthesis process during light stress triggers scarce energy dissipation, thus intensifying ${ }^{1} \mathrm{O}_{2}$ development (Sharma et al., 2012; Smirnoff, 2015). Besides, ascorbic acid also acts as a substrate for antioxidant enzymes such as peroxidase, $\bullet \mathrm{OH}$ radical electron donor, and violaxanthin deepoxidase cofactor (Rezayian et al., 2019;
Smirnoff, 2015; Smerilli et al., 2019). Moreover, the increase in ascorbic acid may be attributed to the suppression of $\mathrm{H}_{2} \mathrm{O}_{2}$ in the ascorbate-glutathione pathway, which serves as a hydrogen donor to turn $\mathrm{H}_{2} \mathrm{O}_{2}$ into water and monodehydroascorbate molecules (Rezayian et al., 2019; Zhang et al., 2020). Ascorbic acid production in microalgae under stressors is still poorly recognized (Kováčik et al., 2017).

$\alpha$-Tocopherol plays a crucial function in oxidative stress scavenger. A significant difference $(p<0.05)$ in $\alpha$-tocopherol content was observed for UMT-M1 and CT in this study but not $\mathrm{CB}$ in 24:0 hours and 12:12 hours L/D photoperiod as shown in Figure 5. The $\alpha$-tocopherol content of UMT-M1 and CT was higher in 24:0 hours L/D culture, with the accumulation of 12.534 \pm 0.127 and $12.840 \pm 0.546 \mathrm{mg} / \mathrm{g} F W$, respectively. These findings were consistent with Durmaz (2007), where Nannochloropsis sp. accumulated high levels of $\alpha$-tocopherol accumulated under continuous light exposure. Contrary to CB's outcome, I. galbana developed higher $\alpha$-tocopherol in continuous light compared to 8:16 hours L/D period (Bandarra et al., 2003). Therefore, our findings suggest that continuous light stimulated $\alpha$-tocopherol output in UMT-M1 and CT, but not in CB.

$\alpha$-Tocopherol (vitamin E) is a lipophilic antioxidant in thylakoid membranes or plastid of microalgae (Papalia et al., 2019). The increase in $\alpha$-tocopherol under continuous illumination can result from the defense of microalgae membrane lipids from photosynthesis-derived ROS, mainly in photosystem II (PSII) (Sharma et al., 2012). The protection mechanism uses scavenge ${ }^{1} \mathrm{O}_{2}$ resonance energy transfer (Papalia et al., 2019; Smerilli et al., 2019). It is also a well-known chain-breaking molecule among the four tocopherol groups ( $\alpha-, \beta$-, and $\beta$-tocopherols) and is capable of suppressing ${ }^{1} \mathrm{O}_{2}$, reducing $\mathrm{O}_{2}{ }^{--}$and inhibiting lipid peroxidation by blocking ROS development involving inhibition of low-density lipoprotein oxidation (Galasso et al., 2019; Rezayian et al., 2019). Notwithstanding, $\alpha$-tocopherol development in microalgae is rarely examined (Mudimu et al., 2017). Future studies should emphasize microalgal antioxidative responses under different

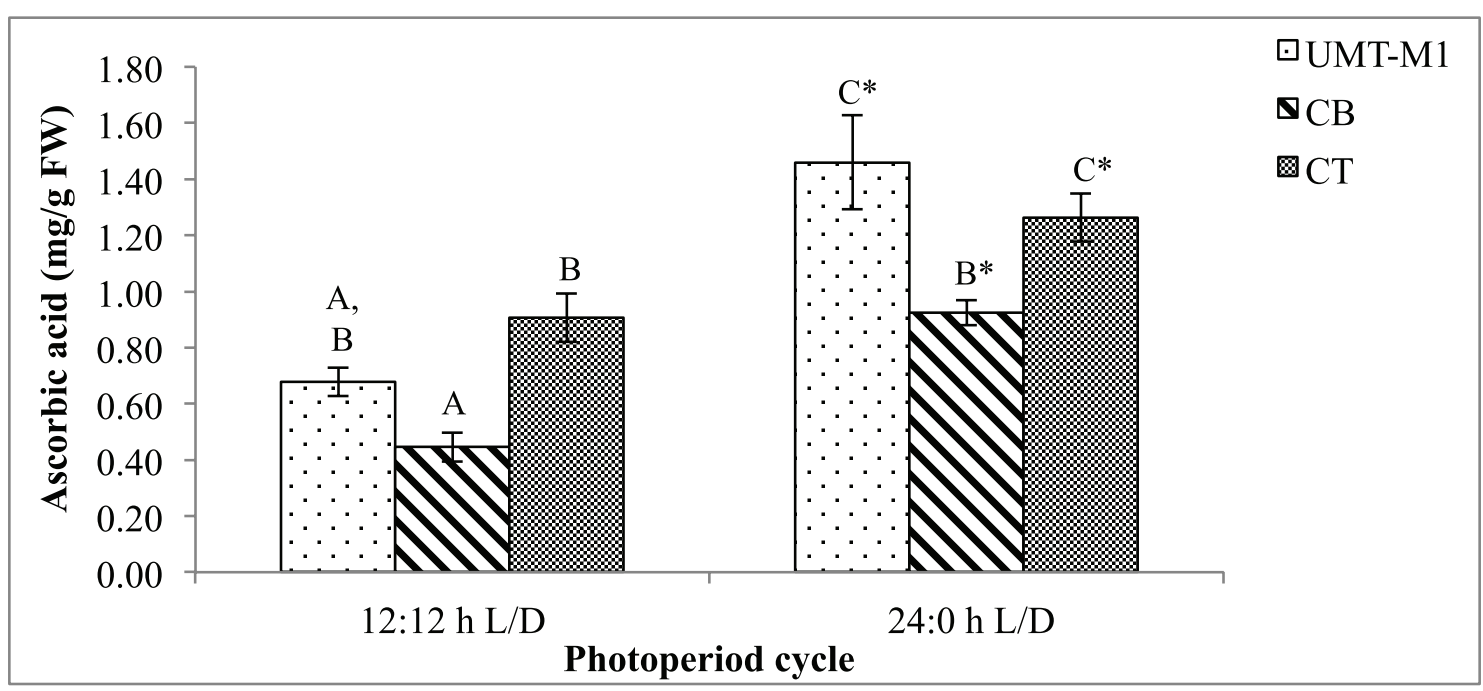

Figure 4. Ascorbic acid contents of UMT-M1, CB, and CT cultivated under 12:12 and 24:0 hours L/D cycles. Data were reported as mean of repetitions \pm standard deviation $(n=3)$. Values with different capital letters $(\mathrm{A}, \mathrm{B}, \mathrm{C}$, and $\mathrm{D})$ were statistically significantly different at $p<0.05$. The asterisk symbol (*) indicates that there was a significant difference between 12:12 and 24:0 hours L/D cycles between individual species. 


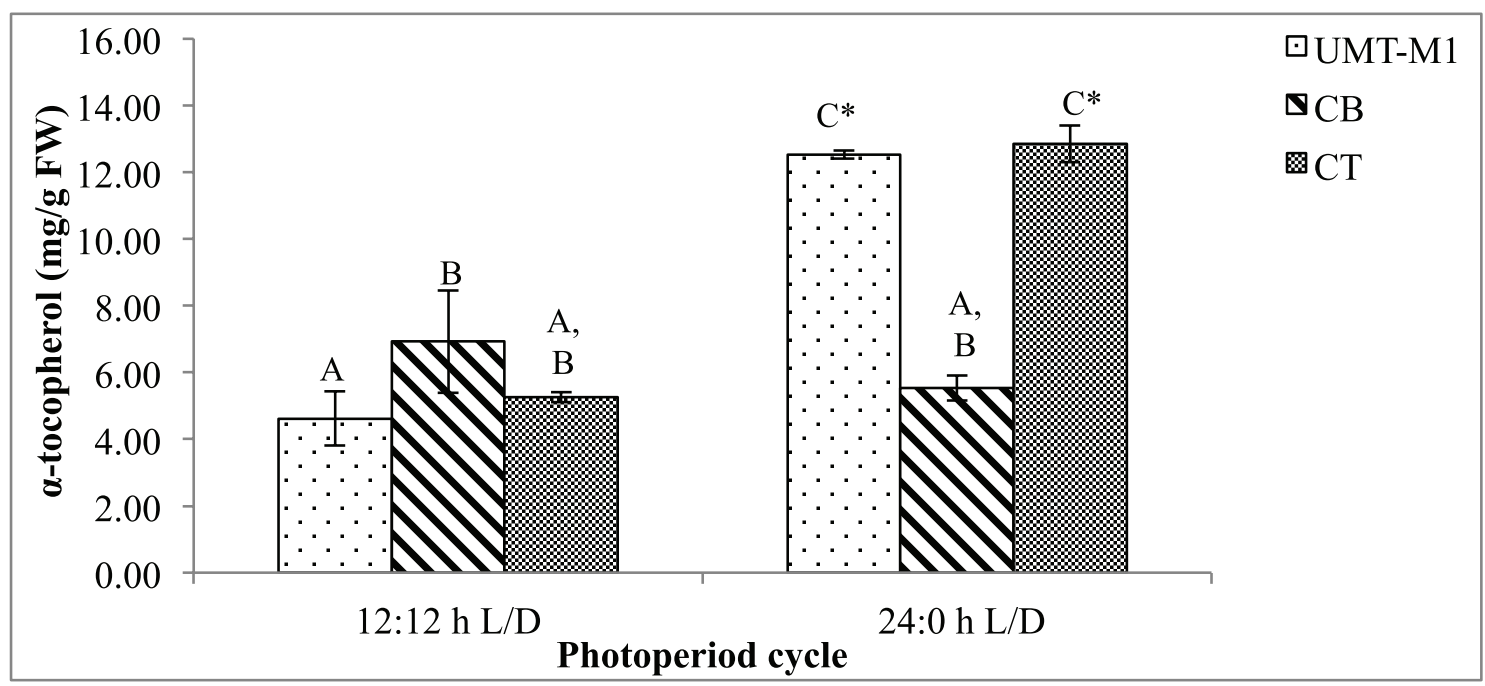

Figure 5. $\alpha$-Tocopherol contents of UMT-M1, CB, and CT cultivated under 12:12 and 24:0 hours L/D cycles. Data were reported as mean of repetitions \pm standard deviation $(n=3)$. Values with different capital letters $(\mathrm{A}, \mathrm{B}, \mathrm{C}$, and D) were statistically significantly different at $p<0.05$. The asterisk symbol (*) indicates that there was a significant difference between 12:12 and 24:0 hours L/D cycles between individual species.

Table 2. Pearson's correlation coefficients of cell density, biomass, and antioxidative responses.

\begin{tabular}{|c|c|c|c|c|c|c|c|c|}
\hline Variables & Cell density & $\begin{array}{c}\text { Wet } \\
\text { biomass }\end{array}$ & $\begin{array}{c}\text { Dry } \\
\text { biomass }\end{array}$ & $\begin{array}{c}\text { Chlorophyll } \\
\text { a }\end{array}$ & $\begin{array}{c}\text { Chlorophyll } \\
\text { b }\end{array}$ & Carotenoids & $\begin{array}{c}\text { Ascorbic } \\
\text { acid }\end{array}$ & $\alpha$-Tocopherol \\
\hline Cell density & 1 & & & & & & & \\
\hline Wet biomass & $0.521^{*}$ & 1 & & & & & & \\
\hline Dry biomass & 0.435 & $0.896^{* *}$ & 1 & & & & & \\
\hline Chlorophyll a & $0.677^{* *}$ & $0.754 * *$ & $0.702^{* *}$ & 1 & & & & \\
\hline Chlorophyll b & 0.401 & $0.770^{* *}$ & $0.754 * *$ & $0.891^{* *}$ & 1 & & & \\
\hline Carotenoids & $0.614^{* *}$ & $0.893 * *$ & $0.807 * *$ & $0.950^{* *}$ & $0.898^{* *}$ & 1 & & \\
\hline Ascorbic acid & 0.191 & $0.757 * *$ & $0.771^{* *}$ & $0.750^{* *}$ & $0.896^{* *}$ & $0.825^{* *}$ & 1 & \\
\hline$\alpha$-Tocopherol & 0.211 & $0.665^{* *}$ & $0.707 * *$ & $0.538^{*}$ & $0.810 * *$ & $0.614^{* *}$ & $0.753 * *$ & 1 \\
\hline
\end{tabular}

The asterisk symbol $(*)$ in a column represents a statistically significant difference at the 0.05 level (2-tailed). The asterisk symbol $(* *)$ in a column represents a statistically significant difference at the 0.01 level (2-tailed).

environmental stressors to provide a practical understanding of cellular adaptation mechanisms and selection of the best stresstolerant microalgae species for future pharmaceutical applications.

\section{Correlation between cell density, biomass, and antioxidant responses}

The relationship between cell density, biomass (wet and dry), and antioxidant responses (chlorophyll a, chlorophyll b, carotenoids, ascorbic acid, and $\alpha$-tocopherol) with Pearson's correlation coefficient (R) was accessed as shown in Table 2.

Cell density showed a significant positive correlation of $0.521,0.677$, and 0.614 , respectively, to wet biomass, chlorophyll $\mathrm{a}$, and carotenoids. In comparison, there was no significant correlation between dry biomass cell density, chlorophyll b, ascorbic acid, and $\alpha$-tocopherol. Due to cellular water content, microalgae cells are strongly affiliated, but the content varies by species, cell size, and light exposure (Chioccioli et al., 2014). Most unicellular microalgae have single or multiple chloroplasts per cell that contribute to the interactive division of microalgae cells and chloroplast (Sumiya, 2018), thus correlating with chlorophyll a and carotenoids output. Biomass (wet and dry) has a strong association with chlorophyll a and chlorophyll b, indicating that chlorophyll concentration serves as an indirect measurement of biomass concentration (Bauer et al., 2017).

Carotenoids demonstrated a strong positive correlation with cell density, biomass, and other antioxidant responses. Among them, two major associations were observed between carotenoids and chlorophyll a $(R=0.980, p<0.01)$, as well as carotenoids and chlorophyll b $(R=0.898, p<0.01)$, which show a direct link between chlorophylls and carotenoids in light-harvesting reactions and their protective function against oxidative stress (Sirisuk et al., 2018). Furthermore, chlorophylls, carotenoids, ascorbic acid, and $\alpha$-tocopherol have a clear association, and it can be expected that they have a strong synergistic contribution to scavenge photosynthetic-derived ROS, as previously stated by Papalia et al. (2019). The results of these Pearson's correlation coefficients provide insight into the relationship between independent variables in this analysis, where most variables are highly interconnected, so it can be further manipulated to seek the best optimum growth conditions with high-value content. 


\section{CONCLUSION}

Different microalgae species respond differently to photoperiod treatment. This study revealed continuous light exposure enhanced growth and antioxidative responses of $C$. vulgaris, I. galbana, and T. chuii. This study suggests that chlorophylls, carotenoids, ascorbic acid, and $\alpha$-tocopherol have cooperative functions in quenching oxidative stress. Chlorella vulgaris, I. galbana, and T. chuii are good candidates for natural antioxidants to replace synthetic antioxidants in the industry, but more studies are needed to find ways to optimize the production of antioxidants from these microalgae.

\section{ACKNOWLEDGMENTS}

This project was funded by the Science and Technology Research Partnership for Sustainable Development (SATREPS), Japan Science and Technology Agency (JST), Japan International Cooperation Agency (JICA), and Ministry of Higher Education Malaysia (MOHE) under Vot No. 53221. Heartfelt thanks are due to the staff at the Institute of Marine Biotechnology (IMB), Centre of Research and Field Service (CRAFS), and Institute of Oceanography (INOS), Universiti Malaysia Terengganu, Terengganu, Malaysia, for their technical support.

\section{AUTHORS' CONTRIBUTIONS}

YYS, HAZ, MEAW, and NY contributed to the conception and design of the work; NSY did the data acquisition, analysis, and data interpretation. NSY drafted the manuscript in consultation with NY; all authors discussed the results and critically reviewed the manuscript; and NY, YYS, MEAW, and HAZ were responsible for giving the final approval of the manuscript.

\section{CONFLICT OF INTEREST}

The authors declared that they do not have any conflicts of interest.

\section{FUNDING}

This work was funded by the Science and Technology Research Partnership for Sustainable Development (SATREPS), Japan Science and Technology Agency (JST), Japan International Cooperation Agency (JICA), and Ministry of Higher Education Malaysia (MOHE) under Vot No. 53221.

\section{REFERENCES}

Ahmad MT, Shariff M, Md. Yusoff F, Goh YM, Banerjee S. Applications of microalga Chlorella vulgaris in aquaculture. Rev Aquac, 2020; 12(1):328-46.

Aratboni HA, Rafiei N, Garcia-Granados R, Alemzadeh A, Morones-Ramírez JR. Biomass and lipid induction strategies in microalgae for biofuel production and other applications. Microb Cell Fact, 2019; 18(1):178

Assunção MF, Amaral R, Martins CB, Ferreira JD, Ressurreição S, Santos SD, Varejão JMTB, Santos LM. Screening microalgae as potential sources of antioxidants. J Appl Phycol, 2017; 29(2):865-77.

Bandarra NM, Pereira PA, Batista I, Vilela MH. Fatty acids, sterols and $\alpha$-tocopherol in Isochrysis galbana. J Food Lipids, 2003; 10(1):25-34.

Barkia I, Saari N, Manning SR. Microalgae for high-value products towards human health and nutrition. Mar Drugs, 2019; 17(5):304.

Bauer LM, Costa JA, da Rosa AP, Santos LO. Growth stimulation and synthesis of lipids, pigments and antioxidants with magnetic fields in Chlorella kessleri cultivations. Bioresour Technol, 2017; 244:1425-32.
Beneragama CK, Goto K. Chlorophyll a: b ratio increases under low-light in 'shade-tolerant' Euglena gracilis. Trop Agric Res, 2010; 22(1):12-25.

Chandra TS, Deepak RS, Kumar MM, Mukherji S, Chauhan VS, Sarada R, Mudliar SN. Evaluation of indigenous fresh water microalga Scenedesmus obtusus for feed and fuel applications: effect of carbon dioxide, light and nutrient sources on growth and biochemical characteristics. Bioresour Technol, 2016; 207:430-9.

Che CA, Kim SH, Hong HJ, Kityo MK, Sunwoo IY, Jeong GT, Kim SK. Optimization of light intensity and photoperiod for Isochrysis galbana culture to improve the biomass and lipid production using 14-L photobioreactors with mixed light emitting diodes (LEDs) wavelength under two-phase culture system. Bioresour Technol, 2019; 285:121323.

Chioccioli M, Hankamer B, Ross IL. Flow cytometry pulse width data enables rapid and sensitive estimation of biomass dry weight in the microalgae Chlamydomonas reinhardtii and Chlorella vulgaris. PLoS One, 2014; 9(5):e97269.

Chong JF, Fadhullah W, Lim V, Lee CK. Two-stage cultivation of the marine microalga Chlorella salina for starch and carbohydrate production. Aquac Int, 2019; 27(5):1269-88.

Darvehei P, Bahri PA, Moheimani NR. Model development for the growth of microalgae: a review. Renew Sustain Energy Rev, 2018; 97:233-58.

De Alvarenga LV, Almeida AVM, de Castro NV, Oder JC, Esteves-Ferreira A, Nunes-Nesi A, Araújo WL, Vaz MGMV. Physiological responses to light intensity and photoperiod of the halotolerant cyanobacterium Desmonostoc salinum CCM-UFV059. Bioresour Technol Rep, 2020; 11:100443.

Durmaz Y. Vitamin E ( $\alpha$-tocopherol) production by the marine microalgae Nannochloropsis oculata (Eustigmatophyceae) in nitrogen limitation. Aquaculture, 2007; 272(1-4):717-22.

Galasso C, Gentile A, Orefice I, Ianora A, Bruno A, Noonan DM, Sansone C, Albini A, Brunet C. Microalgal derivatives as potential nutraceutical and food supplements for human health: a focus on cancer prevention and interception. Nutrients, 2019; 11(6):1226.

George B, Pancha I, Desai C, Chokshi K, Paliwal C, Ghosh T, Mishra S. Effects of different media composition, light intensity and photoperiod on morphology and physiology of freshwater microalgae Ankistrodesmus falcatus $-\mathrm{a}$ potential strain for bio-fuel production. Bioresour Technol, 2014; 171:367-74.

Gonzalez-Camejo J, Viruela A, Ruano MV, Barat R, Seco A, Ferrer J. Effect of light intensity, light duration and photoperiods in the performance of an outdoor photobioreactor for urban wastewater treatment. Algal Res, 2019; 40:101511.

Guillard RR, Smith, M.L. and Chanley, M.H., Eds. Culture of phytoplankton for feeding marine invertebrates. In Culture of marine invertebrate animals. Springer, Boston, MA, pp 29-60, 1975.

Guillard RRL, Ryther JH. Studies of marine planktonic diatoms I. Cyclotella nana Hustedt and Detonula confervacea Cleve. Can J Microbiol, 1962; 8(2):229-39.

Hamidi M, Kozani PS, Kozani PS, Pierre G, Michaud P, Delattre C. Marine bacteria versus microalgae: who is the best for biotechnological production of bioactive compounds with antioxidant properties and other biological applications? Mar Drugs, 2020; 18(1):28.

Kato Y, Fujihara Y, Vavricka CJ, Chang JS, Hasunuma T, Kondo A. Light/dark cycling causes delayed lipid accumulation and increased photoperiod-based biomass yield by altering metabolic flux in oleaginous Chlamydomonas sp. Biotechnol Biofuels, 2019; 12(1):1-11.

Khan MI, Shin JH, Kim JD. The promising future of microalgae: current status, challenges, and optimization of a sustainable and renewable industry for biofuels, feed, and other products. Microb Cell Fact, 2018; 17(1):36.

Khoeyi ZA, Seyfabadi J, Ramezanpour Z. Effect of light intensity and photoperiod on biomass and fatty acid composition of the microalgae, Chlorella vulgaris. Aquac Int, 2012; 20(1):41-9.

Khorobrykh S, Havurinne V, Mattila H, Tyystjärvi E. Oxygen and ROS in photosynthesis. Plants, 2020; 9(1):91. 
Kong W, Son H, Cao Y, Yang H, Hua S, Xia C. The characteristics of biomass production, lipid accumulation and chlorophyll biosynthesis of Chlorella vulgaris under mixotrophic cultivation. Afr J Biotechnol, 2011; 10(55):11620-30.

Kováčik J, Klejdus B, Babula P, Hedbavny J. Ascorbic acid affects short-term response of Scenedesmus quadricauda to cadmium excess. Algal Res, 2017; 24:354-9.

Krzemińska I, Pawlik-Skowrońska B, Trzcińska M, Tys J. Influence of photoperiods on the growth rate and biomass productivity of green microalgae. Bioprocess Biosyst Eng, 2014; 37(4):735-41.

Levasseur W, Taidi B, Lacombe R, Perre P, Pozzobon V. Impact of seconds to minutes photoperiods on Chlorella vulgaris growth rate and chlorophyll a and b content. Algal Res, 2018; 36:10-6.

Lichtenthaler HK, Wellburn AR. Determinations of total carotenoids and chlorophylls a and b of leaf extracts in different solvents. Biochem Soc Trans, 1983; 11:591-2.

Ma R, Thomas-Hall SR, Chua ET, Eltanahy E, Netzel ME, Netzel G, Lu Y, Schenk PM. LED power efficiency of biomass, fatty acid, and carotenoid production in Nannochloropsis microalgae. Bioresour Technol, 2018; 252:118-26.

Maroneze MM, Siqueira SF, Vendruscolo RG, Wagner R, de Menezes CR, Zepka LQ, Jacob-Lopes E. The role of photoperiods on photobioreactors-A potential strategy to reduce costs. Bioresour Technol, 2016; 219:493-9.

Matos ÂP, Cavanholi MG, Moecke EHS, Sant'Anna ES. Effects of different photoperiod and trophic conditions on biomass, protein and lipid production by the marine alga Nannochloropsis gaditana at optimal concentration of desalination concentrate. Bioresour Technol, 2017; 224:490-7.

Medved VO, Gorbunova ZN, Vitovetska TV. Peculiarities of accumulation of proteins, carbohydrates and lipids in the cells of green algae under different light conditions and photoperiod. Hydrobiol J, 2020; 56(3):97-104

Mobin SM, Chowdhury H, Alam F. Commercially important bioproducts from microalgae and their current applications-a review. Energy Procedia, 2019; 160:752-60.

Morales M, Hélias A, Bernard O. Optimal integration of microalgae production with photovoltaic panels: environmental impacts and energy balance. Biotechnol Biofuels, 2019; 12(1):239.

Mudimu O, Koopmann IK, Rybalka N, Friedl T, Schulz R, Bilger W. Screening of microalgae and cyanobacteria strains for $\alpha$-tocopherol content at different growth phases and the influence of nitrate reduction on $\alpha$-tocopherol production. J Appl Phycol, 2017; 29(6):2867-75.

Negi S, Barry AN, Friedland N, Sudasinghe N, Subramanian S, Pieris S, Holguin FO, Dungan B, Schaub T, Sayre R. Impact of nitrogen limitation on biomass, photosynthesis, and lipid accumulation in Chlorella sorokiniana. J Appl Phycol, 2016; 28(2):803-12.

Nethravathy MU, Mehar JG, Mudliar SN, Shekh AY. Recent advances in microalgal bioactives for food, feed, and healthcare products: commercial potential, market space, and sustainability. Compr Rev Food Sci Food Saf, 2019; 18(6):1882-97.

Norhayati Y, Afzan AW, Jannah SSN, Nurul Wahidah MR. Antioxidative responses of Cocos nucifera against infestation by the Red Palm Weevil (RPW), Rhynchophorus ferrugineus, a new invasive coconut pest in Malaysia. Sains Malaysiana, 2016; 45(7):1035-40.

Noshi M, Mori D, Tanabe N, Maruta T, Shigeoka S. Arabidopsis clade IV TGA transcription factors, TGA10 and TGA9, are involved in ROSmediated responses to bacterial PAMP flg22. Plant Sci, 2016; 252:12-21.

Papalia T, Sidari R, Panuccio MR. Impact of different storage methods on bioactive compounds in Arthrospira platensis biomass Molecules, 2019; 24(15):2810.

Patel AK, Joun JM, Hong ME, Sim SJ. Effect of light conditions on mixotrophic cultivation of green microalgae. Bioresour Technol, 2019; 282:245-53.

Perrine Z, Negi S, Sayre RT. Optimization of photosynthetic light energy utilization by microalgae. Algal Res, 2012; 1(2):134-42.
Ramaraj R, Tsai DD, Chen PH. Chlorophyll is not accurate measurement for algal biomass. Chiang Mai J Sci, 2013; 40(4):547-55.

Ren HY, Dai YQ, Kong F, Xing D, Zhao L, Ren NQ, Ma J, Liu BF. Enhanced microalgal growth and lipid accumulation by addition of different nanoparticles under xenon lamp illumination. Bioresour Technol, 2020; 297:122409.

Rezayian M, Niknam V, Ebrahimzadeh H. Oxidative damage and antioxidative system in algae. Toxicol Rep, 2019; 6:1309-13.

Safafar H, Van Wagenen J, Møller P, Jacobsen C. Carotenoids, phenolic compounds and tocopherols contribute to the antioxidative properties of some microalgae species grown on industrial wastewater. Mar Drugs, 2015; 13(12):7339-56.

Sahastrabuddhe AP. Counting of RBC and WBC using image processing: a review. Int J Res Eng Technol, 2016; 5(05):356-60.

Sansone C, Brunet C. Promises and challenges of microalgal antioxidant production. Antioxidants, 2019; 8(7):199.

Sharma P, Jha AB, Dubey RS, Pessarakli M. Reactive oxygen species, oxidative damage, and antioxidative defense mechanism in plants under stressful conditions. J Bot, 2012; 2012:1-26.

Sirisuk P, Ra CH, Jeong GT, Kim SK. Effects of wavelength mixing ratio and photoperiod on microalgal biomass and lipid production in a two-phase culture system using LED illumination. Bioresour Technol, $2018 ; 253: 175-81$

Smerilli A, Balzano S, Maselli M, Blasio M, Orefice I, Galasso C, Sansone C, Brunet C. Antioxidant and photoprotection networking in the coastal diatom Skeletonema marinoi. Antioxidants, 2019; 8(6):154.

Smirnoff $\mathrm{N}$. The evolution of vitamin C biosynthetic pathways in plants and algae. Free Radic Biol Med, 2015; 86:S10.

Sumiya N. Mechanism of coordination between cell and chloroplast division in unicellular algae. Plant Morphol, 2018; 30(1):83-9.

Szymańska R, Ślesak I, Orzechowska A, Kruk, J. Physiological and biochemical responses to high light and temperature stress in plants Environ Exp Bot, 2017; 139:165-77.

Tan JS, Lee SY, Chew KW, Lam MK, Lim JW, Ho SH, Show PL. A review on microalgae cultivation and harvesting, and their biomass extraction processing using ionic liquids. Bioengineered, 2020; 11(1):116-29.

Torres PB, Chow F, Furlan CM, Mandelli F, Mercadante A, Santos DYACD. Standardization of a protocol to extract and analyze chlorophyll a and carotenoids in Gracilaria tenuistipitata Var. Liui. Zhang and Xia (Rhodophyta). Braz J Oceanogr, 2014; 62(1):57-63.

Vendruscolo RG, Fagundes MB, Maroneze MM, do Nascimento TC, de Menezes CR, Barin JS, Zepka LQ, Jacob-Lopez E, Wagner R. Scenedesmus obliquus metabolomics: effect of photoperiods and cell growth phases. Bioprocess Biosyst Eng, 2019; 42(5):727-39.

Wahidin S, Idris A, Shaleh SRM. The influence of light intensity and photoperiod on the growth and lipid content of microalgae Nannochloropsis sp. Bioresour Technol, 2013; 129:7-11.

White LH, Martin DW, Witt KK, Vogt F. Impacts of nutrient competition on microalgae biomass production. J Chemom, 2014; 28(5):448-61

$\mathrm{Xu}$ Y, Ibrahim IM, Harvey PJ. The influence of photoperiod and light intensity on the growth and photosynthesis of Dunaliella salina (chlorophyta) CCAP 19/30. Plant Physiol Biochem, 2016; 106:305-15.

Ye S, Shao Q, Xu M, Li S, Wu M, Tan X, Su L. Effects of light quality on morphology, enzyme activities, and bioactive compound contents in Anoectochilus roxburghii. Front Plant Sci, 2017; 8:857.

Yu W, Liu Y, Song L, Jacobs DF, Du X, Ying Y, Shao Q, Wu J. Effect of differential light quality on morphology, photosynthesis, and antioxidant enzyme activity in Camptotheca acuminata seedlings. J Plant Growth Regul, 2017; 36(1):148-60.

Zahra SSA, Omidvar F, Mahdi K. Combine effects of temperature and photoperiod on the ascorbic acid of green algae Scenedesmus quadricauda. J Fish Sci Technol, 2017; 6(3):61-73.

Zhang S, He Y, Sen B, Wang G. Reactive oxygen species and their applications toward enhanced lipid accumulation in oleaginous microorganisms. Bioresour Technol, 2020; 307:123234. 
Zhang X, Yuan H, Guan L, Wang X, Wang Y, Jiang Z, Cao L, Zhang X. Influence of photoperiods on microalgae biofilm: photosynthetic performance, biomass yield, and cellular composition. Energies, 2019; 12(19):3724.
How to cite this article:

Yusof NS, Yeong YS, Zakeri HA, Wahid MEA, Ghafar SNA, Yusuf N. Photoperiod influenced the growth and antioxidative responses of Chlorella vulgaris, Isochrysis galbana, and Tetraselmis chuii. J Appl Pharm Sci, 2021; 11(04):125-134. 